\title{
PARITAS, PEKERJAAN DAN PENDIDIKAN BERHUBUNGAN DENGAN PEMILIHAN ALAT KONTRASEPSI MKJP PADA AKSEPTOR KB
}

\author{
Novi Eniastina Jasa ${ }^{1 *}$, Akma Listiana $^{2}$, Risneni $^{3}$ \\ Sekolah Tinggi Ilmu Kesehatan Panca Bhakti \\ *Korespondensi Email: novie81@pancabhakti.ac.id
}

\section{ABSTRACT PARITY, EMPLOYMENT AND EDUCATION RELATED TO THE SELECTION OF MKJP CONTRACEPTION TOOLS ON KB ACCEPTORS}

Introduction : Long Term Contraceptive Method (MKJP) is a contraceptive method used to delay, space out pregnancy, and stop fertility that is used in the long term, which includes IUD (Intra Uterine Device), Implant $(K B)$ and tubectomy. The MKJP failure rate is reported to be 0.2 per thousand users, while the non MKJP method is reported to be more than 10 per thousand users. From this, it can be seen that the MKJP method is more effective in preventing pregnancy in its users.

The purpose of this study was to determine the relationship between parity, employment and education with the selection of Long-term Contraceptive Methods (MKJP) at PMB Rosbiatul.

Method: The research design is correlational descriptive with a cross sectional approach. The population in this study were all MKJP and Non MKJP family planning acceptors who visited PMB Rosbiatul with a total of 194 respondents. The sampling technique in this study is total sampling where the entire population is used as a research sample, namely as many as 194 respondents. The variables in this study were parity, occupation and education with the selection of the MKJP Contraceptive Device. The measuring instrument used is a data collection format in the form of a checklist. This research was carried out from January to August in 2021. The data analysis used was quantitative analysis carried out through univariate analysis to see the distribution of each variable, bivariate analysis using Chi Square.

Results : Of the 194 family planning acceptors, 82 people (42.3\%) used the Long-Term Contraception Method (MKJP) and 112 people (57.7\%) used the Non-MKJP Contraception Method. From 194 there were 123 multiparous (63.4\%), and 71 primiparous (36.6\%). From 194 people, 69 respondents (35.6\%) worked and 125 people (64.4\%) did not work. From 194 people, there are 133 respondents (68.6\%) with higher education and 61 respondents (31.4\%) with low education. From the results of the study, it is known that there is a relationship between the selection of the MKJP KB with maternal education with a $p$ value of 0.002 , there is a relationship between the selection of the MKJP KB with the mother's occupation, with a $p$ value of 0.003 , and there is a relationship between the selection of the MKJP KB with maternal parity with a $p$ value. value 0.003 .

Conclusion: The conclusion of the study is that there is a significant relationship between parity, education and mother's occupation with the choice of long-term contraceptive method (MKJP).

Suggestion : Health workers are expected to be able to provide counseling and information about LongTerm Contraceptive Methods (MKJP) for effectiveness in preventing or spacing pregnancies.

Keywords : parity, employment, education, MKJP

\section{ABSTRAK}

Latar Belakang: Metode Kontrasepsi Jangka Panjang (MKJP) adalah metode kontrasepsi yang digunakan untuk menunda, menjarangkan kehamilan, serta menghentikan kesuburan yang digunakan dalam jangka panjang, yang meliputi IUD (Intra Uterine Device) , Implant (susuk KB) dan tubektomi. Angka kegagalan MKJP dilaporkan sebesar 0,2 perseribu pengguna, sedangkan metode non MKJP dilaporkan terjadi lebih dari 10 perseribu pengguna. Dari hal tersebut terlihat bahwa metode MKJP lebih efektif untuk dapat mencegah terjadinya kehamilan pada penggunanya..

Tujuan dari penelitian ini adalah untuk mengetahui Hubungan paritas, pekerjaan dan pendidikan dengan pemilihan Metode Kontrasepsi jangka Panjang (MKJP) di PMB Rosbiatul.

Metode Penelitian: Design penelitian adalah deskriptif korelasional dengan pendekatan cross sectional. Populasi pada penelitian ini adalah semua akseptor KB MKJP dan Non MKJP yang mengunjungi PMB Rosbiatul dengan jumlah 194 responden. Tekhnik pengambilan sample pada penelitian ini adalah total sampling dimana seluruh populasi di jadikan sample penelitian yaitu sebanyak 194 responden. Variabel dalam penelitian ini adalah 


\section{JKM (Jurnal Kebidanan Malahayati),Vol 7,No.4.Oktober 2021, ISSN (Print) 2476-8944 ISSN (Online) 2579-762X, Hal 744-750}

paritas, pekerjaan dan pendidikan dengan pemilihan Alat Kontrasepsi MKJP. Alat ukur yang digunakan adalah format pengumpulan data berupa checklist. Penelitian ini dilaksanakan pada bulan Januari sampai bulan Agustus pada tahun 2021. Analisis data yang digunakan adalah analisis kuantitatif dilakukan melalui analisis univariat untuk melihat distribusi masing-masing variabel, analisis bivariate menggunakan Chi Square.

Hasil penelitian: Dari 194 akseptor KB sebanyak 82 orang ( 42,3\%) menggunakan Metode Kontrasepsi Jangka Panjang (MKJP) dan sebanyak 112 orang $(57,7 \%)$ menggunakan Metode Kontrasepsi Non MKJP. Dari 194 ada 123 multipara (63,4\%), dan 71 Orang primipara (36,6\%). Dari 194 orang sebesar 69 responden $(35,6 \%)$ bekerja dan 125 orang $(64,4 \%)$ tidak bekerja. Dari 194 orang terdapat 133 responden $(68,6 \%)$ pendidikan tinggi dan 61 responden $(31,4 \%)$ pendidikan rendah. Dari hasil penelitian diketahui terdapat hubungan antara pemilihan KB MKJP dengan pendidikan ibu dengan nilai p.value 0,002 , terdapat hubungan antara pemilihan KB MKJP dengan pekerjaan ibu, dengan nilai $p$ value 0,003 , dan terdapat hubungan antara pemilihan KB MKJP dengan paritas ibu dengan nilai p.value 0,003 .

Kesimpulan: Ada hubungan yang signifikan antara paritas, pendidikan dan pekerjaan ibu dengan pemilihan metode kontrasepsi jangka panjang (MKJP).

Saran: Bagi tenaga kesehatan diharapkan dapat memberikan konseling serta informasi tentang Metode Kontrasepsi Jangka Panjang (MKJP) untuk efektifitas dalam mencegah atau menjarangkan kehamilan

Kata Kunci: paritas, pekerjaan, pendidikan, MKJP

\section{PENDAHULUAN}

Jumlah angka kematian lbu yang dihimpun dari pencatatan program kesehatan keluarga di Kementerian Kesehatan pada tahun 2020 menunjukkan 4.627 kematian di Indonesia. Jumlah ini menunjukkan peningkatan dibandingkan tahun 2019 sebesar 4221 kematian. Demikian pula di provinsi lampung AKI mengalami peningkatan dari 111 menjadi 115/100.000 kelahiran hidup. Hal ini masih jauh dari target SDGs (Sustainable Development Goals) dimana target AKI Global SDGs adalah 70/100.000 kelahiran hidup (Profil Kesehatan Indonesia, 2020). Upaya percepatan penurunan AKI dilakukan dengan menjamin agar setiap ibu mampu mengakses pelayanan kesehatan ibu yang berkualitas, salah satunya pelayanan keluarga berencana termasuk KB pasca persalinan (Profil Kesehatan Indonesia, 2020).

Indonesia merupakan negara berkembang dengan peningkatan jumlah penduduk yang sangat tinggi. Hingga tahun 2018, Indonesia menempati urutan keempat sebagai negara berpenduduk terbesar dunia dengan jumlah penduduk mencapai sekitar 265 juta jiwa. Untuk itu pemerintah menggalakkan program KB sebagai upaya untuk menjarangkan kehamilan karena berkaitan erat dengan kesehatan dan kesejahteraan ibu dan anak. (Jitiwiyono, 2019). Pelayanan program KB pelaksanaanya senantiasa terintegrasi dengan kegiatan kelangsungan hidup ibu, bayi dan anak serta penanggulangan masalah kesehatan. Dengan adanya program $\mathrm{KB}$ tersebut menyebabkan berkembangnya berbagai metode kontrasepsi, namun tidak semua alat kontrasepsi efektifitasnya tinggi dalam mencegah kehamilan.
Metode kontrasepsi dibagi dua menurut jangka waktu pemakaiannya, yaitu metode kontrasepsi jangka pendek (Non MKJP) dan metode kontrasepsi jangka panjang (MKJP). Metode kontrasepsi jangka panjang merupakan metode kontrasepsi yang dapat dipakai dalam waktu lama lebih dari dua tahun, memiliki banyak keuntungan, baik dilihat dari segi program maupun dari segi klien. Disamping itu Metode kontrasepsi jangka panjang dapat mempercepat penurunan Total Fertility Rate (TFR) karena memiliki efektifitas tinggi untuk mencegah kehamilan. Kontrasepsi yang tergolong MKJP adalah Implant, IUD, MOW dan MOP. Angka kegagalan MKJP dilaporkan sebesar 0,2 per 1000 pengguna, sedangkan non MKJP terjadi lebih dari 10 per 1000 pengguna. Dari hal tersebut terlihat bahwa metode MKJP lebih efektif untuk dapat mencegah terjadinya kehamilan (Prawirohardjo, 2014). Namun minat masyarakat dalam menggunakan metode kontrasepsi jangka panjang masih rendah dibandingkan metode kontrasepsi jangka pendek. Berdasarkan pola pemilihan jenis Alat kontrasepsi pada tahun 2020 menunjukkan bahwa sebagian besar akseptor memilih menggunakan metode kontrasepsi jangka pendek dibandingkan metode kontasepsi jangka panjang, sehingga tingkat efektifitas dalam pengendalian kehamilan lebih rendah. Di Provinsi Lampung pada tahun 2020 jumlah PUS 1.232.133, cakupan peserta KB aktif sebanyak 68,7\%. Presentase penggunaan alat kontrasepsi IUD sebanyak $36.314(4,29 \%)$, MOW sebanyak 6.337 $(0,75 \%)$, MOP sebanyak $3.133(0,37 \%)$, Implan sebanyak $81.556(9,64 \%)$, suntik sebanyak 593.235 $(70,10 \%)$, kondom sebanyak $7.086(0,84 \%)$, dan pil 


\section{Novi Eniastina Jasa, Akma Listiana, Risneni}

sebanyak $118.629(14,02 \%)$. Jumlah akseptor KB IUD sebanyak 4,29\% dan implant sebanyak 9,64\% lebih rendah dibandingkan akseptor KB pil $(14,02 \%)$ dan suntik $(70,10 \%)$ (Profil Kesehatan Indonesia, 2020).

Rendahnya penggunaan MKJP ini menimbulkan masalah yaitu tingginya angka kegagalan penundaan kehamilan. Penggunaan metode kontrasepsi MKJP dipengaruhi oleh beberapa faktor diantaranya faktor pekerjaan, pendidikan dan paritas. Pendidikan berarti bimbingan yang diberikan seseorang kepada orang lain terhadap suatu hal agar mereka dapat memahaminya. Makin tinggi pendidikan seseorang semakin mudah pula mereka menerima informasi, sebaliknya, tingkat pendidikan seseorang yang rendah akan menghambat perkembangan sikap seseorang terhadap penerimaan, informasi, dan nilai-nilai yang baru diperkenalkan (Jitiwiyono, 2019). Hal ini sejalan dengan penelitian Syukaisih yang berjudul Faktor-faktor yang berhubungan dengan pemilihan kontrasepsi di puskesmas Rambah Samo Kabupaten Rokan Hulu, dimana variabel pendidikan berhubungan dengan pemilihan kontrasepsi dengan nilai $p$ value 0,037 . Demikian pula hasil penelitian dari Windasari lbrahim dengan judul penelitian Hubungan usia, pendidikan dan paritas dengan penggunaan AKDR di puskesmas Doloduo kabupaten Bolang Mongondow, untuk variabel pendidikan berhubungan dengan pemilihan AKDR dan nilai $p$ value 0,002 .

Perkembangan dan kemajuan program KB di Indonesia dipengaruhi pula oleh faktor ekonomi penduduk yang ditentukan dengan variabel pendapatan dan pengeluaran. Tingkat pendapatan suatu keluarga ditentukan dari pekerjaan anggota keluarga tersebut dan sangat berpengaruh terhadap pemilihan metode kontrasepsi. Faktor pekerjaan juga menyebabkan suntikan KB terlambat, karena wanita yang bekerja lupa untuk melaksanakan KB kembali karena terlalu sibuk bekerja, sehingga dibutuhkan dukungan dari anggota keluarga yang lain, khususnya untuk mengingatkan kunjungan kembali. (Jitiwiyono, 2019). Hal ini juga sesuai dengan penelitian Pipih Salanti dengan judul penelitian Faktor-faktor yang berhubungan dengan pemilihan alat kontrasepsi IUD pada ibu di RSIA Resti Mulya Jakarta Timur, didapat bahwa variabel pekerjaan memiliki hubungan erat dengan penggunaan alat kontrasepsi IUD dengan $p$ value 0,015 .

Paritas adalah seorang wanita yang pernah melahirkan bayi yang dapat hidup (viable). Semakin tinggi paritas, maka semakin beresiko kehamilannya. Untuk itu wanita dengan paritas tinggi diharapkan mengikuti program $\mathrm{KB}$ dan memilih metode KB MKJP dimana efektifitasnya lebih tinggi (Prawirohardjo, 2014). Demikian pula dengan penelitian yang dilakukan oleh Tuljanah Lating lating dengan judul penelitian faktor-faktor yang berhubungan dengan pemilihan metode kontrasepsi Jangka panjang (MKJP) dimana hasil penelitian menunjukkan hubungan yang signifikant antara variabel paritas dengan pemilihan MKJP dengan nilai $p$ value 0,030 .

Menurut study pendahuluan yang dilakukan di PMB Rosbiatul pada bulan januari sampai dengan april tahun 2021 terdapat 82 akseptor KB. Akseptor KB MKJP sebanyak 25 orang dan sebanyak 57 akseptor KB non MKJP. Dari 25 akseptor KB MKJP, sebanyak 4 orang berpendidikan rendah, 6 orang tidak bekerja dan 9 orang primipara. Untuk itu penulis tertarik melakukan penelitian Hubungan paritas, pekerjaan dan pendidikan dengan pemilihan Alat Kontrasepsi MKJP.

\section{METODE PENELITIAN}

Jenis penelitian yang dilakukan adalah penelitian deskriptif dengan pendekatan cross sectional. Teknik pengambilan sample yang digunakan adalah total sampling. Penelitian ini dilakukan dari bulan januari sampai bulan Agustus 2021 di PMB Rosbiatul. Data yang diperoleh merupakan data sekunder yang didapatkan dari rekam medik akseptor KB. Populasi pada penelitian ini adalah seluruh akseptor KB MKJP dan Non MKJP di PMB Rosbiatul pada bulan Januari sampai Desember 2020, teknik pengambilan sample pada penelitian ini adalah total sampling dimana seluruh populasi dijadikan sample penelitian dengan jumlah 194 akseptor KB. Variabel pada penelitian ini adalah paritas, pekerjaan dan pendidikan dengan pemilihan Alat Kontrasepsi MKJP. Analisa data yang digunakan adalah analisa univariat dan bivariat. 
Tabel 1.

\begin{tabular}{|c|c|c|}
\hline Variabel & Frekuensi & $\%$ \\
\hline \multicolumn{3}{|l|}{ Akseptor KB } \\
\hline MKJP & 82 & 42,3 \\
\hline Non MKJP & 112 & 57,7 \\
\hline \multicolumn{3}{|l|}{ Pendidkan Ibu } \\
\hline Tinggi & 133 & 68,6 \\
\hline Rendah & 61 & 31,4 \\
\hline \multicolumn{3}{|l|}{ Pekerjaan Ibu } \\
\hline Bekerja & 69 & 35,6 \\
\hline Tida bekerja & 125 & 64,4 \\
\hline \multicolumn{3}{|l|}{ Paritas lbu } \\
\hline Multipara & 123 & 63,4 \\
\hline Primipara & 71 & 36,6 \\
\hline
\end{tabular}

Bivariat

Tabel 2.

Tabel hubungan pemilihan KB MKJP dengan Pendidikan Ibu

\begin{tabular}{|c|c|c|c|c|c|c|}
\hline \multirow{3}{*}{ Variabel } & \multicolumn{4}{|c|}{ KB } & \multirow{3}{*}{ Jumlah } & \multirow{3}{*}{ Nilai $p$} \\
\hline & \multicolumn{2}{|c|}{ MKJP } & \multicolumn{2}{|c|}{ Non MKJP } & & \\
\hline & $\mathrm{N}$ & $\%$ & $\mathrm{~N}$ & $\%$ & & \\
\hline \multicolumn{7}{|l|}{ Pendidikan Ibu } \\
\hline Tinggi & 66 & 49,6 & 67 & 50,4 & 133 & 0,002 \\
\hline Rendah & 16 & 27,6 & 45 & 72,4 & 61 & \\
\hline \multicolumn{7}{|l|}{ Pekerjaan Ibu } \\
\hline Bekerja & 39 & 56,4 & 30 & 43,5 & 69 & \\
\hline Tidak bekerja & 43 & 34,4 & 82 & 65,6 & 125 & 0,003 \\
\hline \multicolumn{7}{|l|}{ Paritas Ibu } \\
\hline Multipara & 62 & 50,4 & 61 & 49,6 & 123 & 0003 \\
\hline Primipara & 20 & 28 & 51 & 72 & 71 & 0,003 \\
\hline
\end{tabular}

\section{PEMBAHASAN}

Pada analisa univariat dari 194 peserta KB yang menggunakan KB non MKJP (Metode Kontrasepsi jangka Panjang) adalah yang terbanyak yaitu $57,7 \%$ dibandingkan dengan yang menggunakan KB MKJP. Sedangkan pada penelitian Suryanti (2019) yang menggunakan MKJP lebih banyak dari 9,4\% dibandingkan dengan non MKJP. Pada akseptor KB MKJP dan non MKJP dilihat dari segi pendidikan yang terbanyak adalah pendidikan tinggi yaitu $68,6 \%$, untuk pekerjaan lebih banyak ibu yang tidak bekerja yaitu $64,4 \%$ dan untuk paritas terbanyak adalah multipara yaitu $63.4 \%$. Metode Kontrasepsi Jangka Panjang (MKJP) merupakan metode dengan tingkat keberhasilan yang tinggi dan angka kegagalan yang rendah, penggunaannya pun bisa bertahan selama 3 tahun bahkan ada yang seumur hidup (Sulistyawati, 2014). Pemerintah selalu mensosialisasikan penggunaan metode MKJP dalam upaya menurunkan laju pertumbuhan penduduk, semakin banyak yang menggunakan maka diharapkan dapat terjadi penurunan angka kelahiran. Walaupun saat ini metode MKJP masih kurang diminati seperti penelitian IImi dkk (2021) penggunaan MKJP sangat sedikit dibandingkan ibu yang menggunakan metode non MKJP. Begitu juga penelitian yang dilakukan oleh Weni dkk (2019) bahwa kontrasepsi non MKJP lebih populer digunakan oleh ibu. Oleh karena itu sebagai tenaga kesehatan harus lebih mendukung upaya pemerintah dalam menyukseskan metode MKJP. Dengan membagikan informasi kegunaan dan manfaat MKJP setiap ibu yang datang untuk mendapatkan pelayanan KB ketika berkunjung ke fasilitas kesehatan. 


\section{Hubungan antara pendidikan dengan pemilihan alat kontrasepsi MKJP}

Pada analisa bivariat di tabel 5 bahwa yang berpendidikan tinggi 49,6 \% menggunakan MKJP dan 50,4 \% tidak menggunakan MKJP, sedangkan yang berpendidikan rendah $27,6 \%$ menggunakan MKJP dan 72,4 \% tidak menggunakan MKJP. Hasil uji chi squaqre yaitu $p$ value 0,002 sehingga ada hubungan antara pemilihan alat kontrasepsi MKJP dengan pendidikan ibu. Seseorang yang memiliki pendidikan lebih tinggi ia lebih mudah menerima informasi sehingga pengetahuan yang dimilikinya makin banyak sedangkan pendidikan rendah dapat mengambat perkembangan sikap dalam menerima informasi dan nilai-nilai yang baru diperkenalkan (Jitowiyono, 2019). Sejalan dengan penelitian Indahwati, dkk (2017) pendidikan seorang ibu memiliki pengaruh terhadap pemilihan kontrasespi MKJP. Penelitian yang dilakukan oleh Rosidah (2020) tingkat pendidikan juga mempengaruhi pemilihan metode MKJP. Begitu juga penelitian yang dilakukan oleh Ningrum dkk (2018) pendidikan mempengaruhi penggunaan metode KB MKJP, dengan tingginya pengetahuan seseorang maka ia lebih mudah berpikir kritis dan realistis sehingga informasi yang di dapat mudah diserap dengan baik. Penelitian Ibrahim dkk (2019) pendidikan juga mempengaruhi dalam memilih metode MKJP, ibu dengan pendidikan yang rendah sangat sedikit yang berani menggunakan metode ini karena merasa takut dan malu dikarenakan kurangnya memahami penggunaan metode ini, informasi yang didapat dari orang yang salah juga bisa menyebabkan efek negatif bagi ibu. Ibu dengan pendidikan lebih tinggi lebih mudah memutuskan pemilihan kontrasepsi MKJP dengan nilai efektivitas yang lebih baik dibandingkan dengan kontrasepsi non MKJP, kerena ia lebih mudah menerima tentang manfaat KB MKJP dan tidak takut atau khawatir akan efek sampingnya karena berpikir manfaat yang diperoleh lebih besar. Dalam menerima informasi pun seorang ibu yang memiliki pendidikan tinggi akan lebih mudah menganalisa informasi yang baik atau tidak baik, sehingga sangat mempengaruhi dalam pengambilan keputusan.

\section{Hubungan antara pekerjaan dengan pemilihan alat kontrasepsi MKJP}

Analisa di tabel 6 penggunaan MKJP pada ibu yang bekerja sebanyak 56,4 \% sedangkan non MKJP $43,5 \%$, pada ibu yang tidak bekerja menggunakan MJKP sebanyak $34,4 \%$ dan yang tidak menggunakan MKJP sebanyak $65,6 \%$. Pada uji chi square didapatkan hasil 0,003 sehingga didapatkan hubungan antara penggunakan MKJP terhadap pekerjaan ibu. Seorang wanita yang memiliki pemasukan yang lebih baik cenderung akan memilih metode kontrasepsi yang lebih mahal, juga lebih mudah mengambil keputusan dalam memilih, lebih bebas memilih tanpa aturan ketat yang mengharuskan mendapat persetujuan suami (Jitowiyono,2019). Dalam penelitian yang dilakukan oleh Budiarti, dkk(2017) bahwa ada keterkaitan erat antara pekerjaan ibu dengan pemilihan metode kontrasepsi jangka panjang (MKJP), dengan bekerja seorang ibu akan memiliki wawasan dan pergaulan yang lebih luas sehingga informasi didapatkan lebih banyak dan dapat dengan mudah memilih kontrasepsi yang lebih efektif dan efisien untuknya. Sejalan dengan Triyanto dan Indriani (2018) pekerjaan memiliki pengaruh dalam memilih metode MKJP, ibu yang bekerja akan merasa lebih aman dalam menggunakan metode ini, karena memiliki pengaruh jangka panjang sehingga ibu tidak terganggu dengan karirnya. Ibu yang bekerja secara otomatis memiliki penghasilan sendiri, ia dapat dengan bebas menggunakan penghasilannya untuk menunjang pemeliharaan kesehatannya termasuk dalam memilih alat kontrasepsi apa yang dirasa baik untuk dirinya, dengan melihat manfaat lebih banyak, efektifitas lebih tinggi serta dapat dipakai dengan waktu yang lebih lama dibandingkan dengan kontrasepsi non MKJP. Dengan kemampuan menghasilkan pendapatan sendiri ibu menginginkan taraf kesehatan yang lebih baik untuk diri dan keluarganya karena dengan menggunakan MKJP berarti ibu bisa merawat anaknya lebih baik karena jarak antara anak yang satu dengan yang lainnya bisa diatur sesuai dengan keinginan ibu dan suami.

\section{Hubungan antara paritas dengan pemilihan alat kontrasepsi MKJP}

Hasil analisa di tabel 7 menunjukkan bahwa dengan multipara yang menggunakan MKJP 50,4 \% dan yang non MKJP 49,6 \%, sedangkan ibu primipara dengan MKJP $28 \%$ dan non MKJP $72 \%$. Hasil analisa chi square 0,003 sehingga terdapat hubungan antara paritas dan pemilihan alat kontrasepsi MKJP. Paritas yang lebih tinggi akan beresiko pada kehamilan dan persalinannya, sehingga untuk mengurangi resiko komplikasi dalam kehamilan dan persalinannya maka ibu harus menjarangkan atau mambatasi jumlah kehamilannya dengan menggunakan metode kontrasepsi (prawirohardjo,2014). Sejalan dengan penelitian yang dilakukan oleh Aningsih dkk(2019) bahwa paritas mempengaruhi sesorang ibu dalam memilih alat kontrasepsi MKJP. Begitu juga menurut Masruroh dan Laili (2018) terdapat 


\section{JKM (Jurnal Kebidanan Malahayati),Vol 7,No.4.Oktober 2021, \\ ISSN (Print) 2476-8944 ISSN (Online) 2579-762X, Hal 744-750}

pengaruh yang erat antara paritas dengan pemilihan alat kontrasepsi MKJP, ibu multipara lebih cenderung akan memilih kontrasepsi jangka panjang. Hal yang sama juga dinyatakan dalam penelitian Laput (2020) bahwa ada keterkaitan paritas ibu dalam pemilihan metode MKJP, dimana ibu yang memiliki paritas tinggi cenderung akan menggunakan metode MKJP dibandingkan dengan ibu yang hanya memiliki 1 orang anak. Menurut penelitian Wulandari dkk (2016) juga sama bahwa ibu multipara cenderung lebih memilih metode MKJP dengan efektivitas yang lebih tinggi dibandingkan dengan non MKJP. Penelitian Kaafi dan Nurwahyuni (2021) menunjukkan hubungan tertinggi dalam pemilihan MKJP adalah paritas. Ibu yang telah memiliki 2 anak atau lebih cenderung berminat untuk berhenti memiliki anak, apalagi bila usia ibu sudah beresiko tinggi mengalami komplikasi dalam kehamilan dan persalinan. Sehingga pemilihan kontrasepsi MKJP sangat tepat dimana angka keberhasilannya lebih tinggi dibandingkan dengan kontrasepsi non MKJP. Sehingga bidan atau tenaga kesehatan perlu berupaya memberikan informasi yang akurat dan lengkap tentang kontrasepsi MKJP.

\section{KESIMPULAN}

ada hubungan yang signifikan antara paritas, pendidikan dan pekerjaan akseptor KB di PMB Rosbiatul dengan pemilihan metode kontrasepsi jangka panjang (MKJP).

\section{SARAN}

Bagi tenaga kesehatan diharapkan dapat memberikan konseling serta informasi tentang metode kontrasepsi jangka panjang (MKJP) untuk efektifitas dalam mencegah dan menjarangkan kehamilan, serta dari hasil penelitian ini dapat dijadikan gambaran maupun pertimbangan dalam membuat program untuk meningkatkan pengetahuan ibu dan keluarga terkait Metode kontrasepsi Jangka Panjang (MKJP).

\section{DAFTAR PUSTAKA}

Aningsih Dwi, S,B., Irawan, L, Y. (2018). Hubungan umur, tingakt pendidikan, pekerjaan dan paritas terhadap penggunaan metode kontrasepsi jangka panjang (MKJP) di dusun III Desa Pananjung Kecamatan Cangkuang Kabupaten Bandung. Jurnal Kebidanan. 8 (1). 33-40

Budiarti, I., Suherni.,Nuryani, D, \& Hidayat, R. (2017). Determinan Penggunaan Metode Kontrasepsi Jangka Panjang (MKJP). Jurnal Kesehatan. 8 (2). 220-224.
Fitri, A., Trisnaningsih, N., \& Suwarni, N. (2016). Hubungan Tingkat pendidikan penggunaan kontrasepsi dengan jumlah anak yang dilahirkan wanita PUS. Fakultas keguruan dan IImu pendidikan UNILA. 1-13.

Ibrahim Windasari, W, Misar, Y. (2019). Hubungan Usia, pendidikan, dan paritas dengan penggunaan AKDR di Puskesmas Doloduo Kabupaten Bolang Margondow. Akademika Jurnal IImiah UMGo. 8(1).36-44.

IImi Bahrul, M., Qariah I, N, \& HIdayati, R. (2021). Determinan Penggunaan Metode Kontrasepsi Jangka Panjang (MKJP) di Puskesmas Sungai Jingah. Jurnal akademika Baiturrahim Jambi (JAJB). 10(1). 94-100.

Indahwati, L., Wati Ratna L., \& Wulan Trias, D. (2017). Usia Dan Pengalaman KB berhubungan dengan Pemilihan Metode Kontrasepsi. Jurnal Of Issues In Midwifery. 1-10.

Jitiwiyono, S., \& Rouf, AM. (2019). Keluarga Berencana (KB) dalam perspektif Bidan. Yogyakarta: PT.Pustaka baru.

Kaafi, F,.Atik, N. (2021). Determinan Pemilihan MKJP pada wanita usia subur di Provinsi Jawa Tengah:Analisis Data Susenas 2018. Jurnal Kajian dan pengembangan kesehatan masyarakat. 1 (2). 161-172.

Kemenkes RI. (2021). Data dan Informasi Profil Kesehatan Indonesia Tahun 2020. Jakarta: Kementrian RI 2021

Laput, O,.D. (2020). Pengaruh paritas terhadap penggunaan kontrasepsi Implant di wilayah kerja Puskesmas Waembeleng Kecamatan Ruteng. Jurnal Wawasan Kesehatan. 5 (1). 6-10.

Lating Tuljanah, R.(2019). Faktor-faktor yang berhubungan dengan pemilihan metode kontrasepsi jangka panjang pada akseptor wanita di Puskesmas Melati II Sleman. Program S1 Terapan Universitas Aisyah Yogyakarta. 1-13.

Masruroh, N,.Laili,. U. (2018). Analisis faktor yang mempengaruhi pemilihan metode kontrasepsi jangka panjang pada ibu nifas di BPM Bashori Surabaya. Jurnal Kesehatan Al-Irsyad. 11 (2). 1-9.

Mirawati, Nuriaty, S, \& Wulandatika, D (2018). Analisis Determinan yang berhubungan dengan pemilihan alat kontrasepsi oleh akseptor KB di PMB Tuti Gambut Kabupaten Banjar Kalimantan Selatan. Journal of midwifery and reproduction. 2(1). 31-35. 


\section{Novi Eniastina Jasa, Akma Listiana, Risneni}

Ningrum Widia, A,D,. Y, Easter, D, \& Sugihati. (2018). Faktor-faktor yang berhubungan dengan pemilihan metode kontrasepsi jangka panjang (MKJP) pada pasangan usia subur di wilayah kerja Puskesmas Batanghari Kabupaten Lampung Timur. Jurnal Dunia Kesmas. 7 (4). 196-203

Prawirohardjo, S. (2014). IImu Kandungan. Jakarta: Yayasan Bina Pustaka Sarwono Prawirohardjo

Salanti,Pipih. (2020). Faktor-faktor yang berhubungan dengan pemilihan Alat kontrasepsi IUD pada ibu di RSIA Resti Mulya Jakarta Timur. Jurnal IImiah Kesehatan Delima. 4 (1). 18-28.

Sulisttyawati, A. (2014). Pelayanan Keluarga Berencana. Jakarta: Salemba Medika.

Suryanti, $Y_{, .} \quad$ (2019). Faktor-faktor yang berhubungan dengan penggunaan metode kontrasepsi jangka panjang wanita usia subur. Jambura Journal of health science and research. 1 (1). 21-29.

Syukaesih,. (2015). Faktor-faktor yang berhubungan dengan pemilihan kontrasepsi di Puskesmas Rambah Samo Kabupaten Rokan Hulu. Jurnal Kesehatan Komunitas. 3 (1). 34-40.

Rosidah, K,. (2020). Pengaruh Tingkat Pendidikan dan Usia terhadap penggunaan metode kontrasepsi jangka panjang tahun 2018. Jurnal Kebidanan. 9 (2). 108-114.

Triyanto, L., Diah, I. (2018). Faktor yang mempengaruhi penggunaan jenis metode kontrasepsi jangka panjang (MKJP) pada wanita menikah usia subur di provinsi Jawa Timur. The Indonesian Journal of Public Health. 13(2). 244-255

Weni, L,. Yuwono, M,. \& Idris, H. (2019). Determinan pemilihan metode kontrasepsi jangka panjang pada akseptor KB aktif di puskesmas Pedamaran. Scientific periodical of public health and coastal. 1 (1). 9-15.

Wulandari, Y., Taufik, M., Ridha, A. (2016). Faktorfaktor yang Mempengaruhi Penggunaan Metode Kontrasepsi Jangka Panjang (MKJP) pada Pasangan Usia Subur di Kabupaten Sambas. Universitas Muhammadiyah Pontianak. 